UNIVERSITY OF WORCESTER

Patterns of innovation in UK industry exploring the CIS data to contrast high and low technology industries

Howard Cox, Marion Frenz and Martha Prevezer 2002

pp.267-304. 


\title{
Patterns of innovation in UK industry: exploring the CIS data to contrast high and low technology industries
}

\author{
Howard Cox, Marion Frenz and Martha Prevezer
}

\begin{abstract}
This paper is divided into two parts. The first part is an examination of the OECD classification of industries into high, medium and low technology industries, to look at the basis for this classification and to use that as a benchmark with which to classify the Community Innovation Survey (CIS) data for the UK into similar groupings. The industries are ranked according to their research intensities and the rankings between the two datasets are compared. Some features of the UK rankings are highlighted and anomalies between the two datasets pointed out. The second part of the paper goes on to use the OECD classification into high, medium and low technology industries, applied to the CIS dataset, to contrast patterns of innovation in high technology industries with those in low technology industries. We build on the three types of innovation surveyed in the CIS, namely product, process and organisational innovation and contrast those types across high and low technology sectors. The expected relationship between high technology industries and product innovation holds - that enterprises tend to do more product innovation, the higher their research intensity. But process innovation does not conform to this pattern and there is not such a clear division between high and low technology industries. However the way they do process innovations differs with high technology industries more reliant on internal resources whereas lower technology industries tend to do it using external resources in collaboration with others. Organisational innovation is more complex, with certain types of innovation done as widely by lower technology industries as by the more research intensive industries. This supports the idea that all types of innovation should be considered, with the diffusion of ICTs making an impact across the technological spectrum of industries and showing up in various forms of organisational innovation.
\end{abstract}




\section{Section 1: Introduction}

This paper is divided into two parts. The first part is an examination of the OECD classification of industries into high, medium and low technology industries, to look at the basis on which the classification has been done and to use that as a benchmark with which to classify the Community Innovation Survey (CIS) data for the UK into similar groupings. The classification of high technology industries has been on the basis of their research intensity: what proportion research and development (R\&D) is of their production or value added. The justification for this classification lies with the reasoning that innovation and hence growth is associated with high technology, research intensive industry. The importance of technological innovation for the growth, profitability and the survival of business enterprises has been well attested (Stoneman 1994, Geroski, Machin and Van Reenen 1993). Innovation has mostly been associated with research intensive industries, close to the science base. In other words it has been seen as a high technology phenomenon with the focus of innovation being on the creation of new products and processes by those research intensive industries.

The focus of research has therefore been on measuring the inputs into innovation in the form of R\&D expenditures (Cohen and Levinthal 1989) and outputs in the form of patents and patent applications (Mansfield 1986, Pavitt 1987) and on issues such as the appropriability of the returns from research and development which affect the incentives for firms to create new products and processes (Levin et al 1987). The focus has therefore been on the technology being or becoming proprietary to the firm with the knowledge embodied in the technology being tacit and difficult to transmit. Whether the research and development is concentrated in the firm or outside the firm in research institutes or universities is another area of examination, which looks at the relationship between the science base and firms and the conditions under which technological change occurs (Nelson and Winter 1982, Nelson 1993, Nelson and Rosenberg 2000). The creation of technology might start off in the public domain, and the ability of the firm to absorb new technologies has been examined (Cohen and Levinthal 1989,1990). 
The literature has also been concerned with the spatial or geographical aspects of innovation: how far does knowledge spillover into the wider geographical area from its original source (Jaffe 1986, Feldman 1994) and with the size of firms and their ability to innovate and survive (Pavitt, Robson and Townsend 1987, Audretsch 1995). There has also been considerable interest in the clustering of innovations at particular geographical locations, but again focusing on high technology based innovations based on the transmission of knowledge created in the science base or in highly research intensive firms (Swann, Prevezer and Stout 1998). A related strain of enquiry is into the conditions under which the diffusion of proprietary technologies occurs, which examines the speed and conditions under which it becomes profitable and viable for firms to imitate new products and processes (Stoneman 1980,1990). This is the tip of the iceberg of an enormous literature on innovation and new technology, and the spread of new knowledge or technology into the surrounding area.

There are two aspects of innovation studies, to which this paper contributes, which have received relatively little attention. First we wish to broaden out the concept of innovation to incorporate not purely technological innovation but also organisational innovation and to include not only the science based high technology industries with high research intensities but also low technology industries which spend relatively little on R\&D. There is some evidence that different types of innovation technological and organisational - need to be done together to have a positive impact on productivity (Brynjolfsson and Hitt 2000). We therefore need a more detailed assessment not only of technological innovation but also of the stimuli for organisational innovation and to understand which types of firm are succeeding in combining both. There is also relatively little said about the type of industry which tends to be innovative, as the assumption has been that innovation was confined to high technology industry. Our study therefore challenges this assumption and widens the scope of enquiry to include high, medium and low technology industries.

Second, the inclusion of organisational innovations - the introduction of quality management systems, the use of "just in time" systems, the use of electronic means such as email, the internet and EDI to organise production - means that we are also broadening out our concepts of innovation to capture the diffusion not only of proprietary technologies developed by the science base or by firms themselves, but 
the diffusion of generic technologies based on codified knowledge. The focus is not so much on the transmission or transfer of the technologies themselves but on the impact that those ICTs have on the way the firm is structured and operates. This alters the debate about the geography of innovation as we would expect the geographical constraints to the spread of such generic technologies to be less than in the case of tacit proprietary technologies and the boundaries of the firm to become more flexible as a consequence of these technologies.

We are able to adopt this broader approach to innovation largely because new sources of information are becoming available. These are looking at innovation directly, not through R\&D expenditures and patents, but through survey questions and case studies. Recent case study work has looked at the impact of organisational innovation and the introduction of ICT on parts of the food industry, traditionally thought of as a low technology industry but whose supply chain and organisational structure has been transformed by the ability of the retailers to exert control back up the supply chain via their computer systems, alongside their capacity to innovate using their direct access to consumers and the data generated at the point of sale on changing consumer demands. (Cox, Mowatt and Prevezer forthcoming).

The other new sources of information are the innovation surveys conducted across the EU during the 1990s (Edquist et al 2001). In particular we use the second Community Innovation Survey (CIS) for the UK which is seen to be particularly robust in its sampling and completion. What the CIS offers for analysts of innovation is the ability to open out this debate on the sources and components of innovation to include all manufacturing and services industries, most of which were ruled out of the former innovation debate through not being highly research intensive industries. The survey is also able to tackle some of the issues associated with innovation directly, through asking questions about the conditions related to the firm's innovativeness, the sources of information associated with innovations, and the objectives of innovations for example. It represents a major step forward in the comprehensiveness of the enquiry into innovation and enables us to begin to understand whether there are differences between high and low technology industries in their capacities to innovate.

But first we wish to have a clearer understanding of the basis on which the classification of industries into the high/medium/low technology categories has been 
done and whether the OECD classification can be applied to the CIS data for our analysis of innovation in high and low technology industries.

The rest of the paper is organised as follows. Section 2 is a comparison of OECD and CIS classifications. A central aspect of this paper is to examine the classification of industries into high, medium and low technology as done by the OECD and to see:

a) how the UK matches up to the OECD average and what are the anomalies;

b) how the CIS and OECD compare using the OECD measure of R\&D/ production as a basis for classifying high and low technology industries. The aim of this is to be able to use the CIS data and have a standard division into high/medium/low technology that is applicable across the OECD.

Section 3 applies the OECD classification to the CIS data and makes a preliminary examination of the different patterns of innovation between high and low technology industries. In particular it looks at product, process and organisational innovation and looks at whether the expected relationships between high technology industries and product and process innovation hold, and whether the pattern of innovation is different for low technology industries. Section 4 concludes and points to the future direction of research: to examine particular low technology sectors in more detail and to evaluate the impact of innovation on performance of those companies.

\section{Section 2: The Composition of R\&D intensity in the UK: a comparative analysis}

The data used to analyse patterns of innovation in the UK manufacturing industry derives from the second Community Innovation Survey (CIS), a survey undertaken at EU level in 1997. The reference period of the survey is 1994 to 1996 . The CIS, conducted in the UK by the Department of Trade and Industry (DTI), aims at explaining the drivers of innovation in manufacturing as well as in the service sector. The sampling frame used by the DTI is the Inter-Department Business Register (IDBR). The IDBR held information of approximately 155,000 enterprises (i.e. individual places of business; in the case of large firms these would be second- or third-level subsidiaries). A representative sample of 5,892 enterprises was selected, 
representative of the 2-digit industry code level and across eight size groups of firms designated by number of employees. The total number of respondents was 2,342 , giving a response rate of $43.2 \%$. A weight was applied to the respondents group in order to match the number of enterprises on the IDBR ${ }^{1}$. Out of the 2,342 respondents 1,514 enterprises were manufacturers and are examined in this paper. Table 1 breaks down the 1,514 manufacturing firm responses by industry class as derived from the OECD classification of high, medium-high, medium-low and low tech industries. Out of the 1,514 manufacturing enterprises 507 are low technology, 403 medium-low, 426 medium-high and 178 enterprises are categorised as high technology. Coverage of the weighted sample is representative of UK manufacturing industry as a whole, although some sectors (e.g. coke, petroleum and nuclear fuel; shipbuilding; other transport; pharmaceuticals) have to be treated with caution, as the number of companies in each class who responded to the questionnaire does not exceed 20.

Table 1 here.

In order to group the 1,514 manufacturing enterprises of the CIS data set into low, medium and high technology the OECDs 'classification of industries on the basis of technology' has been used. This classification is derived from three measures of R\&D intensity based upon:

i. $\quad$ R\&D expenditure (Intramural) divided by value added ${ }^{2}$

ii. R\&D expenditure (Intramural) divided by production;

iii. $R \& D$ expenditure plus technology embodied in intermediate and investment goods divided by production.

Table 2 here

The three indices were calculated across the aggregate of 10 OECD countries, for which the underlying technology variable was available. The latest available reference

\footnotetext{
${ }^{1}$ See DTI (1998), p. 59.

${ }^{2}$ In the following R\&D expenditure is intramural R\&D expenditure unless otherwise specified; also see OECD (1994), p. 20.
} 
year is $1990 .^{3}$ From Table 2 it can be seen that three quite decisive boundaries can be applied to segment the industry sectors by technology into four groups. The only obvious anomaly is the petroleum refineries and products sector which, when R\&D spending is expressed as a proportion of value added, would be reclassified from a medium-low to a medium high technology industry. Otherwise a clear pattern is established across all three indicators.

In assessing how well the UK manufacturing sector reflects this more general pattern of R\&D intensity it is necessary both to update the information to the 1996 reference period of the CIS and analyse the OECDs own results with respect to the UK. To do this the OECD's STAN 2000 (Structural Analysis) and ANBERD 2000 (Analytical Business Enterprise Research and Development) databases have been used to recalculate R\&D intensity for an equivalent group of leading OECD countries in 1995 (the nearest year for which comparative results are available) and for the UK specifically as of 1996 .

Table 3 here

Table 3 provides a series of rankings for each of 19 industry sectors grouped according to the ISIC revision 3 classification. This is less than the 21 sectors listed in Table 2 due to the amalgamation of ferrous and non-ferrous metals on the one hand and wood, paper and publishing on the other. Updating the OECD group results from 1990 to 1995 is only possible directly for $R \& D$ intensity measured as a ratio against value added. Moreover, the sample of OECD countries included in the updated version has risen from 10 to 14 and thus the two groups are not exactly equivalent. Nevertheless, a comparison of the rankings between columns (2) and (3) of Table 3 shows very close comparability and Table 4 calculates a Spearman rank correlation coefficient between the two sets of ranking of 0.975 , demonstrating that very little variation has occurred over time. It must be stated, however, that due to a variety of factors the OECD ANBERD data on R\&D have frequently been estimated on the basis of returns from individual countries rather than reported directly, and this may

\footnotetext{
${ }^{3}$ See OECD-OCDE (1999), p. 25-27.
} 
have imposed a significant bias towards results across time and between countries that emphasise continuity rather than variation. ${ }^{4}$ Only two points of divergence between the two rankings would seem worthy of discussion. First, the relatively high ranking for petroleum found in the 1990 value added based statistics is no longer evident in 1995 (suggesting that this sector is genuinely medium-low rather than medium-high tech). Second, the higher ranking for scientific instruments moves that sector from medium-high to high tech which may represent a more valid classification (see Table $3 \mathrm{a}$ in the Appendix for a comparison based on the R\&D intensity ratios as well as the pure rankings).

Table 4 here

Turning to a comparison of the OECD group as a whole with the UK component of the OECD ANBERD survey, the rankings given in columns (3) and (5) provide R\&D intensity statistics for the mid-1990s judged against figures for valued added. The Spearman rank correlation coefficient in Table 4 of 0.829 indicates that the UK pattern is broadly similar to that of the OECD 14 group as a whole, but inspection of individual rankings in Table 3 and the $R \& D$ intensities calculated in Table $3 b$ (Appendix) throws up two sharp deviations among the UK results. First is the very high ranking (3) accorded to the petroleum refining industry in the UK figures. Three issues are pertinent in this case:

i. a genuine country-specific effect due to Britain's oil-rich economy;

ii. a company-specific effect in which a proportion of the $R \& D$ spending by companies in the oil sector may relate to, but not be attributed to, other types of activities (e.g. chemicals);

iii. a low value added effect.

\footnotetext{
${ }^{4}$ Particularly important are problems that arise from the fact that some countries do not provide data for R\&D spending each year (and thus some missing annual observations have been simply estimated) and because figures that are reported for diversified industrial enterprises need to be allocated to specific sectors consistently across different countries. For a detailed discussion of the issues addressed in the estimation of the ANBERD statistics cf. OECD (2000a).
} 
This final point is given further credence by the fall in the ranking of the petroleum sector when value added is replaced by production as the basis for calculating the R\&D intensity (see column (4) of Table 3$)^{5}$

A second deviant sector in the OECD ANBERD rankings for the UK is provided by office and computing equipment. Inspection of the OECDs annual figures for this sector identifies a long term decline in the importance of $R \& D$ spending by office and computing equipment firms. Thus in absolute terms, $R \& D$ expenditure in this sector is estimated to have declined from $£ 417 \mathrm{~m}$. in 1990 to $£ 161 \mathrm{~m}$. in 1996 , meaning that as a proportion of total manufacturing R\&D expenditure firms in the UK's office and computing equipment sector have seen their share fall from $6 \%$ to $2 \%$ over the course of six years. ${ }^{6}$ A deeper empirical analysis might usefully be employed to consider whether such a decline has, in fact, occurred.

Severe doubts as to the validity of the OECD results in the case of the UK's office and computing equipment manufacturers are engendered by a comparison with the UK CIS results presented in column (6) of Table 3. This shows that the 42 respondents from the corresponding UK SIC code exhibited a level of R\&D intensity relative to turnover sufficient to rank them second behind scientific instruments. ${ }^{7}$ This result puts the UK office and computing sector exactly in line with the OECD group as a whole and strongly suggests some misrepresentation in the ANBERD statistics. The top ranking accorded to manufacturers of scientific instruments in the CIS UK results also lends strength to the idea that firms in this sector ought to be regarded as high tech manufacturers.

In general the pattern of the rankings generated by the CIS survey varies markedly when compared to the OECD ANBERD findings. The correlation coefficient between

\footnotetext{
${ }^{5}$ Overall the impact of changing the basis for calculating the UK R\&D intensity ratio from value added to production does not have a marked impact on the ranking. The Spearman rank correlation coefficient for the two sets of rankings is 0.963 (see Table 4).

${ }_{7}^{6}$ OECD (2000a) pp. 130-1.

${ }^{7}$ In calculating the turnover of the respondents our figures have used an unweighted average of the two years' turnover reported, i.e. 1994 and 1996, rather than simply that reported for 1996. The thinking behind this has been that annual variations in sales (turnover) are likely to be greater than those relating to production and that by using an average figure we will reduce the impact on the results of reported turnovers that happen to be atypical. Naturally, the impact on the absolute value of the R\&D intensity ratio thus calculated will normally be to bias it upward, since only R\&D expenditure figures for 1996 are reported in the survey. This bias in the absolute value will have no impact on the ordinal rankings, however.
} 
the two rankings of UK R\&D intensity by sector using the most similar ratio production and turnover (columns (4) and (6) in Table 3 ) - is actually lower (0.675) than that between the CIS UK rankings and those produced by the OECD 10 rankings of 1990 based on production ratios (0.730) (see Table 4). This provides prima facie evidence to suggest that, at least in the case of the UK, some of the OECD country specific figures are unrepresentative.

Three other points of divergence between the CIS and OECD figures for the UK (see also Table 3c in Appendix) are worthy of discussion. The first is that the UK petroleum industry reverts to its ranking within the medium-low tech industries. A possible reason for this may be the level at which the data has been collected. Whereas the OECD data appears to have been collected at the level of corporate headquarters ${ }^{8}$ the CIS surveyed individual plants or enterprises. The corporate R\&D budgets of UK-based oil firms may include a portion that is actually spent outside of Britain, or in sectors other than oil and hence may be upwardly biased. On the other hand, the CIS survey contains results from only 15 enterprises in the two-digit category that encompasses oil refining and is thus a small sample even though the results in Table $3 \mathrm{c}$ have been weighted to allow for the effect of firm size. The overall conclusion would seem to be that oil is a medium-low tech industry but one that exhibits a highly uneven geographical pattern to its R\&D expenditure.

Tables 5 here

Two sectors that have relatively low rankings in the UK CIS results are aircraft and motor vehicles. In the OECD figures for the UK they are ranked 2 and 6 respectively, whilst in the CIS results that they emerge as 10 and 13. Clearly neither of these industries could be considered to be on the low range of the technology spectrum which thus raises the question of whether the CIS results are unrepresentative or whether they are representative and the UK is simply not a key location for either of

\footnotetext{
${ }^{8}$ The OECD papers are not very clear about the actual nature of the respondents to their questionnaire on resources devoted to R\&D. The data are collected in line with the recommendations of the Frascati Manual whose practice it is to report R\&D on an enterprise basis. However, it is clear that the OECD interpretation of an enterprise differs from that used by the CIS in constructing its representative sample of UK firms at the enterprise level. In the OECD case, an enterprise may be diversified to the point where it may engage in $\mathrm{R} \& \mathrm{D}$ expenditure across a range of areas and hence disaggregation becomes a serious problem. The data for the CIS survey, by contrast, was collected at a level that made such problems of allocating an enterprise's R\&D to a specific sector practically redundant.
} 
these activities. In both cases these are component assembly industries and Table 5 breaks down the 72 two-digit respondents to the CIS survey into three three-digit subsectors (see Appendix 2). The CIS sample frame was intended only to be representative at the two-digit level, and it is interesting to discover from Table 5 that only seven of the 72 respondents in the UK sample are drawn from the motor vehicles subsector (341). The remainder are component manufacturers, illustrating Britain's role as a peripheral motor car manufacturing country. Of the seven respondents who are actually motor vehicle manufacturers, Table 5 a illustrates that only one reported a level of R\&D expenditure in excess of one per cent of turnover.

It would therefore seem that both vehicle manufacturing and aircraft (also a threedigit category) are high tech industries in which the UK plays an extremely limited role. The OECD ANBERD figures for these UK industries would warrant further scrutiny in the light of the CIS findings, particularly since the former appear to have been gathered from diversified parent companies and estimated with a view towards cross-country comparability.

This section has reviewed the results of the UK CIS survey in relation to its findings on the level of R\&D intensities. The classification system developed by the OECD has been utilised to analyse the sectoral pattern of R\&D expenditures. The OECD classification system appears to be generally a valid breakdown of industries by means of high, medium and low technology. It is suggested that scientific instruments may be usefully reclassified as a high tech industry, and that some industries (petroleum, motor vehicles, aircraft) seem much more likely to exhibit cross country variations than others. The OECD ANBERD ranking of the UK office and computing equipment industry is hard to substantiate.

The pattern of $R \& D$ intensity may be expected to reflect the degree or propensity towards innovation in different manufacturing sectors. In itself, however, it is only an input measure and needs to be tested against more direct measures of innovation activity. In the next section of the paper, therefore, the fourfold classification of industries is used to analyse the responses to the CIS survey by enterprises in order to establish to what extent firms who show high levels of R\&D intensity actually report greater innovation in terms of product, process and organisational development. 


\section{Section 3: Application of the OECD classification to look at patterns of innovation, contrasting high, medium and low technology industries}

This section looks at the differences between high, medium-high, medium-low and low technology industries, using the breakdown into the four categories discussed above, in terms of their propensities to innovate. There are six main groups of questions and associated results.

i) We start off with the our main focus on how many enterprises have done product, process and organisational innovation broken down by research intensity. We include a chi square and an ordered probit analysis of the differences between our four categories: low technology, medium-low, medium-high and high technology industries.

ii) We go on to look at how product and process innovation have been implemented: whether externally using other enterprises or institutes, internally by own enterprise, or jointly with other enterprises. In this section we also look at the information sources used by the enterprise to carry out the innovation.

iii) To confirm the OECD classification we look at the CIS results on research intensity, asking how much enterprises have engaged in R\&D.

iv) We then look at the main objectives for innovation: ranging from replacing and improving new products and extending the product range on the one hand to cutting costs of various sorts on the other.

v) We look at whether the enterprises have benefited from government financial assistance.

vi) We look at some performance indicators: the proportion of turnover from new, improved or unchanged products; and the growth in employment, turnover and exports between 1994-1996.

We report all results according to our four categories of research intensity.

These relate to the following questions from the survey: i) to question 1a on product innovation, asking whether the enterprise had introduced onto the market any technologically new or improved products over the period in question, question $2 \mathrm{a}$ on process innovation asking whether the enterprise had introduced any technologically 
new or improved processes and to question 5 on organisational innovation, asking whether the enterprise had introduced any of the following organisational changes or management techniques: electronic data interchange (EDI), "just in time" or similar planning system, use of electronic mail, use of the internet, investors in people, quality management system or Standard (eg ISO9000), benchmarking performance against other firms or any other technique.

ii) relates to question 1a and $2 \mathrm{a}$ on product and process innovation which ask whether new or improved products or processes had been developed mainly by other enterprises and were thus externally acquired, whether they were developed jointly with another enterprise or whether the main source of process innovation had been within the firm and hence internally developed. In this section on how the enterprises implemented innovations we also looked at question 12 on the sources of information for innovation projects which range from being within the enterprise, competitors, clients, suppliers, public sector research organisations, regulations and standards, and networking institutions such as fairs, conferences or computer based networks.

iii) relates to question $8 b$ about $R \& D$ activity - whether the enterprise had engaged in $\mathrm{R} \& \mathrm{D}$ continuously, occasionally or not at all, and this was looked at according to the classification into high, medium-high, medium-low and low technology industry.

iv) relates to question 11 asking about the main objectives of the enterprise in developing or introducing technological innovations, with answers ranging from replacing, improving or extending new products and opening up markets, to fulfilling regulations and standards, to reducing labour, materials, energy or environmental costs.

v) relates to question 15 asking whether the enterprise received central government financial support for innovative activities in 1996 such as loans with a subsidy element or grants.

vi) relates to question 7 asking how much of the enterprise's turnover in 1996 is attributable to technologically new products, improved products or unchanged products; and as performance measures we include information on the growth in number of employees, turnover and exports between 1994 and 1996. 


\section{Results}

i) Tables 6, 7 and 8 give a summary of results as to whether enterprises engaged in product, process or organisational innovation. The expected relationship between product innovation and research intensity holds with over $70 \%$ of medium-high and high technology firms introducing new products compared with 53\% of medium-low tech and $46 \%$ of low technology firms doing product innovation. This distinction, between the two lower technology categories and the two higher technology categories in their propensity to innovate with new products is confirmed by a significant chi square result at the $1 \%$ level as well as a significant $\mathrm{z}$ value on the ordered probit analysis.

Table 6 on proportion of product innovators by research intensity

For process innovation there appears to be much less of a division between high and low technology industries. Overall a substantially lower proportion has done process innovation than product innovation, with around $40 \%$ of the enterprises in the two lower technology categories and around $45 \%$ of those in the the two higher technology categories introducing new or improved processes in the relevant time period. The chi square and ordered probit analysis confirmed that there was no significant difference between the categories of high and low technologies in answering this question.

Table 7 on proportion of process innovators by research intensity

For organisational innovation the proportions of firms in all groups answering yes to this are much higher, with the positive relationship between technological intensity and degree of innovation holding. This is confirmed by a significant chi square and ordered probit $\mathrm{z}$ values for this question. However organisational innovation has been quite widespread, with $70 \%$ of even low technology firms engaging in some form of it. 
Table 8 on proportion of organisational innovators by research intensity

Table 9 looks at the breakdown by research intensity into the various types of organisational innovation that were asked about. For certain types of innovation such as the introduction of EDI, email, investors in people and benchmarking schemes, there is no significant difference between low tech, medium-low tech and mediumhigh technology industries, with only enterprises in the high technology category being more innovative than the rest. This gives the impression that many such organisational innovations are fairly widespread throughout the technological spectrum.

Table 9 Different types of organisational innovations

ii) Table 10 shows how enterprises have implemented their product and process innovations: whether they have developed them internally within their own enterprise, externally through other enterprises or institutes or jointly with other enterprises or institutes.

Table 10 Product and process innovation: internal v external development

Medium-high and high technology industries rely more markedly on internal resources for both product and process innovation than do the lower technology industries, and this is especially true for product innovation. They also do product and process innovation jointly with collaborators more than lower technology industries. 
Lower technology industries rely on purely external resources particularly for process innovation. When one breaks this down to look at particular industries in the low technology sector, there is one group of industries such as food and beverages, textiles and furniture which have tended to rely on internal sources for process innovations, and another group including the leather industry, the publishing industry and the electricity, gas and water industries that have relied on external sources with relatively few engaging in joint innovation in collaboration with others. This might be to do with the size of the firm with larger firms having a tendency to be more insular and self-reliant.

Table 11 shows the information sources used by enterprises to carry out their innovations, according to research intensity. We have grouped the results into five main types of information source: those related to the supply chain and immediate rivals (in line with Porter's diamond analysis 1990); those connected to the public domain, namely universities, government institutes, private non-profit research institutes and patent disclosures; those which are of a networking character namely conferences, fairs and computer-based networks; regulations and standards including environmental, health and safety and product standards; and other public institutions such as research associations, TECs and Business Links.

Table 11 Information sources used by enterprise to carry out innovation

The main results indicate a greater self-reliance ie reliance on sources within the enterprise or enterprise group amongst higher technology enterprises, and with greater reliance on competitors and customers as sources of information used for innovation. However suppliers of equipment or materials are as important for lower technology enterprises as for higher tech ones. This fits in with the greater reliance on external sources for process innovation of lower technology enterprises, noted above. As expected the higher technology enterprises rely more on the public sector research institutions, especially the universities. Patent disclosures seem to be fairly important across the technological spectrum. The networking sources are evenly used across the technological spectrum, with computer based networks and conferences being used by the lower technology enterprises as much as by the higher technology ones. Likewise health and safety and environmental regulation is a spur for lower tech enterprises as 
much as for higher tech ones, although product standards feature more significantly for higher technology enterprises. This fits in with their greater emphasis on product innovation. The other public institutions show no clear pattern across the technological spectrum.

iii) The picture of the higher technology industries relying more on their internal $R \& D$ as a basis for innovation is borne out by the answers to the question on $R \& D$ engagement, where as expected the higher technology sectors place a greater emphasis on continuous R\&D.

Table 12 R\&D Engagement by research intensity

iv) Table 13 shows the results of the main objectives for innovation across the technological spectrum. There is greater emphasis on reducing costs in the low and medium-low technology industries and more weight put on introducing new products and opening up new markets amongst high technology industries. Low technology industries also emphasise improving product quality and production flexibility, perhaps indications of the importance of process innovations as opposed to product innovation.

Table 13

v) Table 14 shows the proportion of enterprises receiving government support or assistance. As expected, the higher the technological intensity, the greater the support through government assistance.

Table 14

vi) Table 15 shows the proportion of turnover deriving from new products, from improved products or from unchanged products, as one of our indicators of performance.

Table 15 proportion of turnover from new products 
By this indicator higher technology enterprises perform better than lower technology ones, as expected with their greater emphasis on the introduction of new products.

Table 16 shows the growth in employment, turnover and exports between 1994-1996 broken down by technological category. In terms of the effects on employment over this period, there is not much difference between the technological categories and the impact is relatively slight. The changes in turnover show a clearer division between lower and higher technology enterprises and for exports, high technology enterprises are in a league of their own. One has to be careful in attributing these changes to the innovation patterns we have been discussing; one would expect the impact of innovation to take a few years to manifest itself in terms of growth of the enterprises. However this acts as a snapshot in time at the different growth rates of these enterprises with different research intensities, which highlights the faster growth in turnover and exports one might expect from higher technology enterprises.

Table 16 Percentage change in employees, turnover and growth

\section{Section 4: Conclusions}

Looking at the first part of the paper in Section 2, we conclude that we can use the OECD classification on the CIS data. The overall ranking in R\&D intensity is very close, between the whole group of OECD countries and the CIS ranking. The four groups - high technology, medium-high technology, medium-low technology and low technology industries - emerge as having quite clear-cut boundaries. The exercise gives us a clearer understanding of how this classification according to research intensity, which is used quite widely especially when looking at high technology industries, has been achieved. Updating the data to the mid-1990s indicates that there has been relatively little variation in ranking over time excepting that scientific instruments should be reclassified as a high technology industry rather than in the medium-high category and that the petroleum industry becomes a medium-low industry rather than a medium-high tech industry as classified by the 1990 data. 
However there are a few anomalies which emerge when we compare the OECD group as a whole with the OECD ANBERD figures for the UK. The OECD ANBERD high ranking of the UK petroleum industry may reflect a country specific effect for the oilrich UK, an inflation of the R\&D figures for the oil industry or a lower figure for value added, on which these data are based, than production. The UK's office and computing equipment industry shows a marked decline in $\mathrm{R} \& \mathrm{D}$ expenditure during the early 1990s which stands at odds with the CIS data.

Turning to the comparison between the CIS data and the OECD ANBERD data for the UK, there is a lower correlation between these two sets of data than between the rankings of the CIS and the OECD as a whole. The CIS classifies the petroleum industry as a medium-low tech one, which reflects a general distinction, that the data are gathered at the enterprise level and not through corporate headquarters, which may lower the R\&D figures, reflecting the uneven $R \& D$ expenditures geographically in the UK. The CIS also gives much lower rankings to the aircraft and motor vehicles industries than does the OECD. The CIS sample is taken mainly from components manufacturers, and these lower rankings reflect the fact that these are really high technology industries but ones in which the UK's role is fairly limited. The examination throws into question some of the methods that the OECD use in collecting their country specific data, as data are collected from diversified parent companies and estimated to create cross-country comparability, which creates distortions when compared with data collected at the enterprise level within each country.

Overall however we can conclude that the OECD classification of the whole group of countries into the four categories of $R \& D$ intensity is a good starting point for an examination of patterns of innovation in the different sectors of UK manufacturing, to which we turned in Section 3.

Our main conclusions from this examination of innovation patterns are the following. First on types of innovation, the relation between product innovation and high technology industries is confirmed - that there is a strong relationship and high technology industries do tend to do more product innovation than lower technology industries. This does relate to higher research intensity, so it appears that higher R\&D 
expenditures do lead to greater product innovation. Process innovation is not such an obvious case, with no clear division between high and low technology industries in their capacity and tendency to do process innovation. For organisational innovation, there is overall a relationship between research intensity and the tendency to do organisational innovation, with high tech industries introducing more organisational innovations. But certain types of organisational innovations are done as widely by low-tech industries as by high tech ones, such as the use of ICTs and benchmarking systems to track the performance of competitors as well as use of schemes such as investors in people. The diffusion of ICTs and some organisational innovations stressing quality appear to be quite widespread across the technological spectrum.

Second, there appears to be a distinction between the higher and lower technology industries in terms of their modes of implementation of innovation. Higher technology industries rely to a greater extent on internal resources, whereas lower technology industries rely much more on external resources and especially so for process innovations. This links in with the answers to various of the other subsidiary questions we looked at: when examining information sources, higher technology industries rely on internal sources and look to information from their own supply chains or immediate competitors whereas lower technology industries look to their networking links and to external regulations and standards. Suppliers of equipment, which may be thought of as important for process innovation, are as important sources of information for lower technology industries as for high-tech industries. Again looking at sources of information or support, the expected relationship between high technology industries relying more on the public sector and especially the universities is confirmed, which relates clearly to their research intensity. Also not surprisingly, given the tenor of government policy, higher technology industries have received more government financial assistance than lower technology industries. The differences in modes of implementation of innovation between higher and lower technology industries is substantiated when one examines their objectives for innovation. Higher technology industries are more focused on developing new products and markets whereas lower technology industries concentrate more on lowering costs of various sorts and on objectives related to process innovations such as increasing production flexibility. 
How are these differences between high and low-tech industries reflected in performance measures? We have only very preliminary performance measures to look at, but these confirm the division between high and low-tech industries. High-tech industries emphasise the introduction of new products with a greater proportion of their turnover reflecting this. In terms of employment, turnover and exports, high tech industries tend to perform better on turnover and exports than do low tech ones, although there is very little difference between high and low tech in terms of job creation, and neither exhibit huge growth in employment. However these data relate only to the period 1994-6 and one would clearly need a longer run of data to examine performance and pick up the effects of innovativeness with any accuracy.

What can we conclude overall? There has been an emphasis on high technology innovation, both in actuality and as reflected in the literature, which has focused on particular types of innovation and particular modes of innovation. The focus has been on the introduction of new products and on a reliance on internal resources and $R \& D$, looking to the immediate supply chain and geared towards opening up new markets. This emphasis appears to be justified when one looks at performance in terms of the growth of turnover and exports.

However it ignores some crucial aspects of innovation which is taking place in lower technology industries. It fails to capture the process innovations and certain types of organisational innovation which are more reliant on external sources and on collaborations, which place greater emphasis on networking links and developing links with equipment suppliers and which have objectives related to process innovation and to reducing costs.

The implications of this are that we need a broader picture of innovation to capture all the various types of innovation that are occurring across the spectrum of research intensity. The diffusion of ICTs is manifesting itself in these other types of process and organisational innovation and should not be left out of the picture. The methods of innovation and the focus or types of innovation are clearly different between the higher and lower technology industries and these differences should be recognised in order to be able to arrive at appropriate policy stimulants for the particular sectors. The performance implications are unclear at this stage of research: we need further 
work with longer runs of data to evaluate fully the impact of innovation on various aspects of performance. Our own work takes us in this direction. We intend to look more fully, through case studies, at lower technology companies, to get a better understanding of how these process and organisational innovations are being implemented and their impact on performance. 


\section{Tables}

\section{Table 1: CIS respondent rate classified by industry.}

Low-technology industries

Food, beverages \& tobacco

Textiles, apparel \& leather

Wood, Furniture

Paper, products \& printing

Electricity, Gas and Water Supply

Collection, Purification \& Distribution of Water

Total

Medium-low technology industries

Coke, Petroleum \& Nuclear Fuel

Rubber and Plastic

Other Non-Metallic Mineral Products

Basic Metals

Fabricated Metal Products

Shipbuilding \& repairing

Recycling

Total

Medium-high technology industries

Chemicals

Machinery and Equipment

Electrical Machinery

Medical / Optical Instruments

Motor Vehicles

Other Transport

Total

High technology industries

Pharmaceuticals, medicines

Office Machinery and Computers

Radio, Television \& Communication

Aircraft, spaceraft

Total

Grand total

$\begin{array}{cc}\text { Frequency } & \text { Percent } \\ 120 & 23.7 \\ 121 & 23.9 \\ 90 & 17.8 \\ 134 & 26.4 \\ 21 & 4.1 \\ 21 & 4.1 \\ 507 & 100.0\end{array}$

Frequency Percent

$\begin{array}{cc}15 & 3.7 \\ 101 & 25.1 \\ 57 & 14.1 \\ 60 & 14.9 \\ 122 & 30.3 \\ 17 & 4.2 \\ 31 & 7.7 \\ 403 & 100.0\end{array}$

Frequency Percent

$\begin{array}{cc}71 & 16.7 \\ 125 & 29.3 \\ 59 & 13.8 \\ 87 & 20.4 \\ 72 & 16.9 \\ 12 & 2.8 \\ 426 & 100.0\end{array}$

Frequency Percent

$\begin{array}{cc}20 & 11.2 \\ 43 & 24.2 \\ 76 & 42.7 \\ 39 & 21.9 \\ 178 & 100.0\end{array}$

1514 
Table 2: Classification of industries based on technology, 1990.

Classification of Industries

High-technology industries

Aircraft

Office \& computing equipment

Drugs \& medicines

Radio, TV \& communication equipment

Medium-high-technology industries

Professional goods

Motor vehicles

Electrical machines excl. commun. equip.

Chemicals excl. drugs

Other transport

Non-electrical machinery

Medium-low technology industries

Rubber \& plastic products

Shipbuilding \& repaiing

Other manufacturing

Non-ferrous metals

Non-metalic mineral products

Metal products

Petroleum refineries \& products

Ferrous metals

\section{Low-technology industries}

Paper, products \& printing

Textiels, apparel \& leather

Food, beverages \& tobacco

Wood products \& furniture

\section{UK SIC 92}

as used in CIS

35.3
30
24.4
32

33
34
31

24 excl. 24.4

35 excl. $35.1+35.3$

29

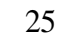

35.1

$27 *$

26

28

23

27

21,22

$17,18,19$

15,16

20,36
R\&D+

$R \& D$

$R \& D$

acquired

technology

as \% of

as $\%$ of

as \% of

production

production value added

$\begin{array}{ccc}17.30 & 14.98 & 36.25 \\ 14.37 & 11.46 & 30.49 \\ 11.35 & 10.47 & 21.57 \\ 9.40 & 8.03 & 18.65\end{array}$

6.55

5.10

11.19

4.44

3.41

13.70

3.96

2.81

7.63

3.84

3.20

8.96

3.03

1.58

3.97

2.58

1.74

4.58

2.47

1.07

3.02

2.21

0.74

2.13

1.76

0.63

1.52

1.57

0.93

3.48

1.44

0.93

2.20

1.35

0.63

1.39

1.33

0.96

8.43

1.10

0.64

2.48

*basic metals

$\begin{array}{lll}0.88 & 0.31 & 0.76 \\ 0.78 & 0.23 & 0.65 \\ 0.73 & 0.34 & 1.14 \\ 0.65 & 0.18 & 0.47\end{array}$

0.76

0.47

.25
.49
.57


.65
.19
.70
.63
.96
.58


3.02
13
.52
.48
.39
.43
.48


Table 3: Industries ranked by $R \& D$ intensity.

\begin{tabular}{|c|c|c|c|c|c|c|c|}
\hline Industry & $\begin{array}{c}\text { ISIC } \\
\text { Rev. } 3\end{array}$ & $\begin{array}{c}1990 \\
\text { OECD - 10 } \\
\text { R\&D } \\
\text { expenditure } \\
\text { as \% of } \\
\text { production } \\
\text { (1) }\end{array}$ & $\begin{array}{c}1990 \\
\text { OECD - 10 } \\
\text { R\&D } \\
\text { expenditure } \\
\text { as \% of } \\
\text { value added } \\
\text { (2) } \\
\end{array}$ & $\begin{array}{c}1995 \\
\text { OECD - 14 } \\
\text { R\&D } \\
\text { expenditure } \\
\text { as \% of } \\
\text { value added } \\
\text { (3) } \\
\end{array}$ & $\begin{array}{c}1996 \\
\text { OECD - UK } \\
\\
\text { R\&D } \\
\text { as \% of } \\
\text { production } \\
\text { (4) }\end{array}$ & $\begin{array}{c}1996 \\
\text { OECD - UK } \\
\\
\text { R\&D } \\
\text { as \% of } \\
\text { value added } \\
\text { (5) }\end{array}$ & $\begin{array}{c}1996 \\
\text { CIS - UK } \\
\text { R\&D } \\
\text { as \% of } \\
\text { turnover } \\
\text { (6) } \\
\end{array}$ \\
\hline \multicolumn{8}{|l|}{ High-tech } \\
\hline Aerospace & 353 & 1 & 1 & 1 & 2 & 2 & 10 \\
\hline Office, computing equip. & 30 & 2 & 2 & 2 & 11 & 10 & 2 \\
\hline Pharmaceuticals & 2423 & 3 & 3 & 3 & 1 & 1 & 3 \\
\hline Radio, TV, communication equip. & 32 & 4 & 4 & 5 & 3 & 4 & 4 \\
\hline \multicolumn{8}{|l|}{ Medium-high-tech } \\
\hline Scientific instruments & 33 & 5 & 6 & 4 & 5 & 7 & 1 \\
\hline Motor vehicles & 34 & 6 & 5 & 6 & 6 & 6 & 13 \\
\hline Electrical machinery & 31 & 8 & 9 & 7 & 4 & 5 & 9 \\
\hline Chemicals & $24 \mathrm{ex} 2423$ & 7 & 7 & 8 & 9 & 9 & 7 \\
\hline Other transport & $35 \mathrm{e} \times 351+353$ & 10 & 11 & 9 & 8 & 8 & 5 \\
\hline Non-electrical machinery & 29 & 9 & 10 & 10 & 10 & 11 & 6 \\
\hline \multicolumn{8}{|l|}{ Medium-low-tech } \\
\hline Rubber, plastic & 25 & 11 & 12 & 12 & 15 & 16 & 16 \\
\hline Shipbuilding & 351 & 15 & 15 & 14 & 12 & 12 & 11 \\
\hline Basic metals* & 27 & 14 & 13 & 13 & 17 & 14 & 19 \\
\hline Non-metalic mineral prod. & 26 & 13 & 14 & 15 & 13 & 13 & 8 \\
\hline Fabricated metal prod. & 28 & 16 & 16 & 16 & 14 & 17 & 12 \\
\hline Petroleum refineries & 23 & 12 & 8 & 11 & 7 & 3 & 14 \\
\hline \multicolumn{8}{|l|}{ Low-tech } \\
\hline Wood, paper, publishing* & $20-22,36-37$ & 17 & 18 & 17 & 19 & 19 & 17 \\
\hline Textiles, apparel, leather & $17-19$ & 19 & 19 & 19 & 18 & 18 & 15 \\
\hline Food, beverages, tobacco & $15-16$ & 18 & 17 & 18 & 16 & 14 & 18 \\
\hline
\end{tabular}


Table 4: Spearman rank correlation coefficient on R\&D classification, OECD and CIS.

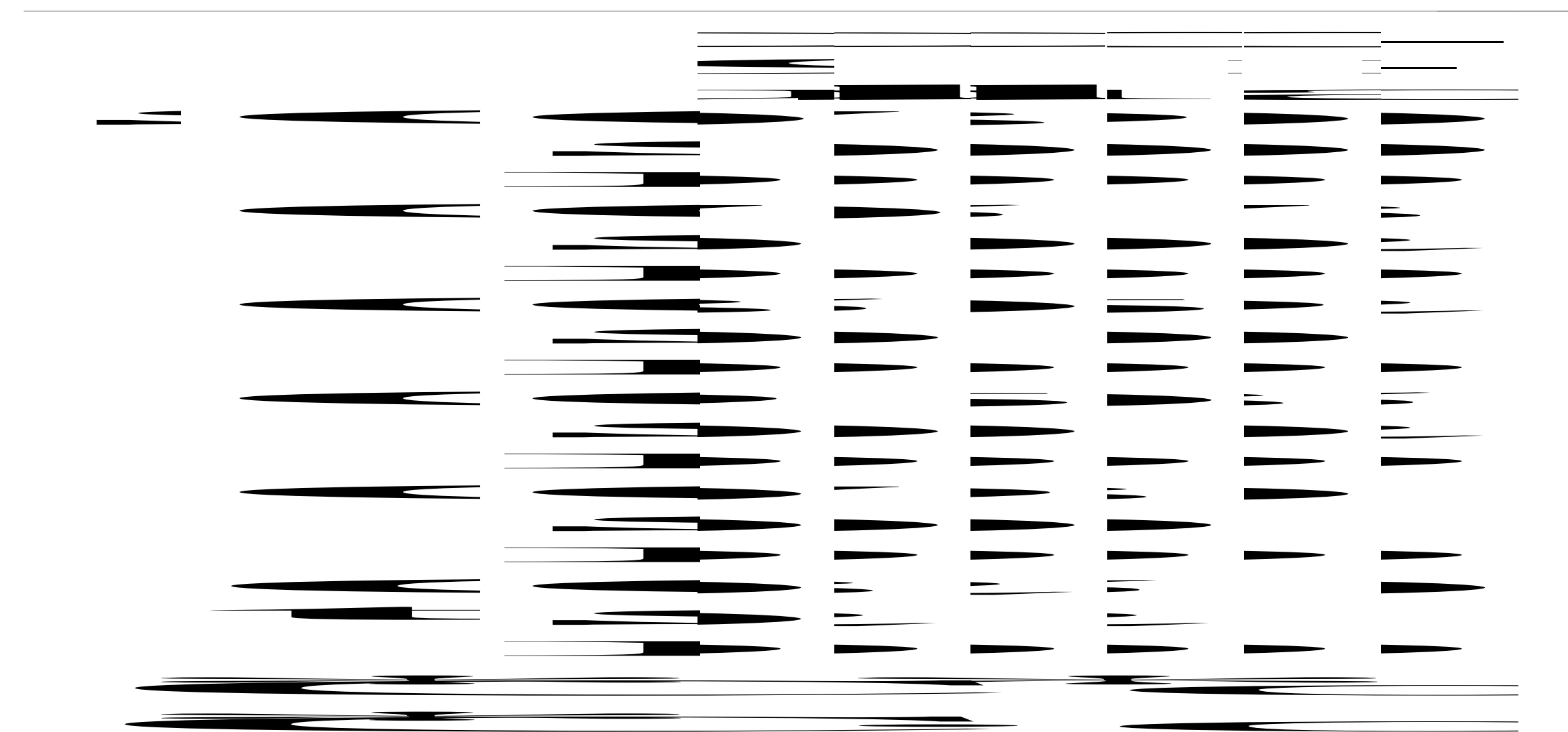


Table 5: R\&D intensity, CIS, 1996, UK manufacturing of motor vehicles.

( $\mathrm{N}=72$, weight2 applied)

\begin{tabular}{lcccc} 
& \multicolumn{1}{c}{$\begin{array}{c}\mathbf{1 9 9 6} \\
\text { CIS } \\
\text { R\&D }\end{array}$} & & \\
Industry Classification & $\mathbf{U K ~ S I C}$ & $\begin{array}{c}\text { as \% of } \\
\text { turnover }\end{array}$ & Frequencies & Rank \\
Motor vehicles & 341 & 0.53 & 7 & 2 \\
Bodies (coachwork) & 342 & 0.34 & 23 & 3 \\
Part, accessories & 343 & 0.61 & 42 & 1 \\
Total & & $\mathbf{0 . 4 6}$ & $\mathbf{7 2}$ & \\
& & & & \\
\hline
\end{tabular}




$\begin{array}{lcccc} & \text { low-tech } & \begin{array}{c}\text { medium- } \\ \text { low-tech }\end{array} & \begin{array}{c}\text { medium- } \\ \text { high-tech }\end{array} & \text { high-tech } \\ \text { no } & 54.0 \% & 47.0 \% & 29.8 \% & 29.2 \% \\ \text { yes } & 46.0 \% & 53.0 \% & 70.2 \% & 70.8 \% \\ \text { Total N } & 507 & 402 & 426 & 178\end{array}$

Chi-square test: $\quad \chi^{2}=71.9$ significant, $p<0.01$

Ordered probit: $\quad \mathrm{Z}=7.99>2.58$ significant, $p<0.01$

\section{Table 7: Proportion of process innovators. CIS data. 1994-1996.}

$$
\text { low-tech } \begin{array}{cc}
\text { medium- } & \text { medium- } \\
\text { low-tech } & \text { high-tech }
\end{array} \text { high-tech }
$$

$\begin{array}{lcccc}\text { no } & 60.2 \% & 61.7 \% & 55.6 \% & 52.2 \% \\ \text { yes } & 39.8 \% & 38.3 \% & 44.4 \% & 47.8 \% \\ \text { Total N } & 507 & 402 & 426 & 178\end{array}$

Chi-square test: $\quad \chi^{2}=6.6$ not significant, $p>0.05$

Ordered probit: $\quad Z=1.89<1.96 \quad$ not significant, $p>0.05$

Table 8: Proportion of organisational innovators. CIS data. 1994-1996.

$\begin{array}{lcccc} & \text { low-tech } & \begin{array}{c}\text { medium- } \\ \text { low-tech }\end{array} & \begin{array}{c}\text { medium- } \\ \text { high-tech }\end{array} & \text { high-tech } \\ \text { no } & 69.4 \% & 72.5 \% & 80.0 \% & 92.1 \% \\ \text { yes } & 30.6 \% & 27.5 \% & 20.0 \% & 7.9 \% \\ \text { Total N } & 507 & 403 & 426 & 178\end{array}$

Chi-square test: $\quad \chi^{2}=43.9$

significant, $p<0.01$

Ordered probit: $\quad Z=5.87>2.58$

significant, $p<0.01$ 


\begin{tabular}{|c|c|c|c|c|}
\hline & low-tech & $\begin{array}{l}\text { medium-low- } \\
\text { tech }\end{array}$ & $\begin{array}{l}\text { medium- } \\
\text { high-tech }\end{array}$ & high-tech \\
\hline Introduction of EDI 1994-1996 & $32.9 \%$ & $26.6 \%$ & $25.8 \%$ & $32.6 \%$ \\
\hline $\begin{array}{l}\text { Introduction of Just in Time or similar planning } \\
\text { system 1994-1996 }\end{array}$ & $12.6 \%$ & $17.4 \%$ & $21.8 \%$ & $26.4 \%$ \\
\hline Introduction of electronic mail 1994-1996 & $34.1 \%$ & $26.8 \%$ & $38.5 \%$ & $59.6 \%$ \\
\hline Introduction of internet 1994-1996 & $27.6 \%$ & $23.8 \%$ & $34.5 \%$ & $57.9 \%$ \\
\hline Introductrotin of IIP 1994-1996 & $19.1 \%$ & $19.9 \%$ & $19.5 \%$ & $27.5 \%$ \\
\hline $\begin{array}{l}\text { Introduction of a quality management system or } \\
\text { standard 1994-1996 }\end{array}$ & $24.5 \%$ & $39.5 \%$ & $46.0 \%$ & $56.2 \%$ \\
\hline $\begin{array}{l}\text { Introduction of a benchmarking system for } \\
\text { performance against other firms 1994-1996 }\end{array}$ & $19.3 \%$ & $20.8 \%$ & $22.3 \%$ & $29.2 \%$ \\
\hline $\begin{array}{l}\text { Introduction of some other change or technique 1994- } \\
1996\end{array}$ & $5.9 \%$ & $5.2 \%$ & $8.0 \%$ & $5.6 \%$ \\
\hline
\end{tabular}

Table 10: Product and process innovation: internal or external development.

\begin{tabular}{lcccccc} 
& \multicolumn{2}{c}{ external } & \multicolumn{2}{c}{ jointly } & \multicolumn{2}{c}{ internal } \\
& product & process & product & process & product & process \\
low-tech & $5.1 \%$ & $15.2 \%$ & $7.3 \%$ & $9.1 \%$ & $19.9 \%$ & $18.7 \%$ \\
medium-low-tech & $4.5 \%$ & $10.2 \%$ & $8.7 \%$ & $8.7 \%$ & $24.6 \%$ & $22.8 \%$ \\
medium-high-tech & $6.1 \%$ & $9.4 \%$ & $13.4 \%$ & $11.7 \%$ & $45.3 \%$ & $28.6 \%$ \\
high-tech & $10.1 \%$ & $10.7 \%$ & $12.9 \%$ & $14.0 \%$ & $43.3 \%$ & $29.8 \%$ \\
& & & & & & \\
\hline
\end{tabular}


Table 11: Information sources used by enterprise to carry out innovation.

\begin{tabular}{|c|c|c|c|c|}
\hline & low-tech & $\begin{array}{l}\text { medium-low- } \\
\text { tech }\end{array}$ & $\begin{array}{l}\text { medium-high- } \\
\text { tech }\end{array}$ & high-tech \\
\hline $\begin{array}{l}\text { Internal, supply chain and } \\
\text { competitors. average }\end{array}$ & $33.1 \%$ & $33.1 \%$ & $44.8 \%$ & $47.0 \%$ \\
\hline $\begin{array}{l}\text { Public sector and non-profit } \\
\text { orgs. average }\end{array}$ & $6.7 \%$ & $9.2 \%$ & $13.4 \%$ & $13.9 \%$ \\
\hline $\begin{array}{l}\text { Networking institutions. } \\
\text { average }\end{array}$ & $25.0 \%$ & $19.3 \%$ & $31.1 \%$ & $39.9 \%$ \\
\hline $\begin{array}{l}\text { Regulations and standards. } \\
\text { average }\end{array}$ & $21.8 \%$ & $27.4 \%$ & $33.3 \%$ & $27.2 \%$ \\
\hline Business links. average & $11.4 \%$ & $10.4 \%$ & $13.3 \%$ & $14.7 \%$ \\
\hline
\end{tabular}

\section{Table 12: R\&D engagement by research intensity.}

continously occasionally not at all

$\begin{array}{lccc}\text { low-tech } & 27.0 \% & 18.7 \% & 54.2 \% \\ \text { medium-low-tech } & 23.3 \% & 24.8 \% & 51.9 \% \\ \text { medium-high-tech } & 45.8 \% & 23.7 \% & 30.5 \% \\ \text { high-tech } & 46.1 \% & 19.7 \% & 34.3 \%\end{array}$


Table 13: Main objectives of an enterprise in developing and introducing technological innovations.

\begin{tabular}{lcccc}
\hline & low-tech & $\begin{array}{c}\text { medium-low- } \\
\text { tech }\end{array}$ & $\begin{array}{c}\text { medium-high- } \\
\text { tech }\end{array}$ & high-tech \\
& $22.9 \%$ & $22.6 \%$ & $33.6 \%$ & $38.2 \%$ \\
$\begin{array}{l}\text { Replace products being phased } \\
\text { out }\end{array}$ & $51.9 \%$ & $47.1 \%$ & $51.4 \%$ & $59.0 \%$ \\
$\begin{array}{l}\text { Improve product quality } \\
\text { Extend product range }\end{array}$ & $29.2 \%$ & $27.8 \%$ & $39.4 \%$ & $40.4 \%$ \\
Open up new markets & $45.0 \%$ & $48.1 \%$ & $61.7 \%$ & $66.9 \%$ \\
$\begin{array}{l}\text { Fulfill regulations, standards } \\
\text { Retain or protect existing } \\
\text { markets }\end{array}$ & $27.6 \%$ & $23.8 \%$ & $30.8 \%$ & $37.1 \%$ \\
Improve production flexibility & $35.5 \%$ & $37.0 \%$ & $47.7 \%$ & $48.9 \%$ \\
Reduce labour costs & $31.2 \%$ & $23.8 \%$ & $28.2 \%$ & $28.1 \%$ \\
Reduce material consumption & $42.4 \%$ & $33.7 \%$ & $34.3 \%$ & $39.3 \%$ \\
Reduce energy consumption & $38.1 \%$ & $29.3 \%$ & $27.0 \%$ & $33.7 \%$ \\
Reduce environmental damage & $26.8 \%$ & $24.6 \%$ & $17.4 \%$ & $22.5 \%$ \\
& $26.6 \%$ & $26.3 \%$ & $24.2 \%$ & $22.5 \%$ \\
\hline
\end{tabular}

\section{Table 14: Financial support or assistance by the government. CIS.}

$$
\begin{array}{ccc}
\text { low-tech } & \begin{array}{c}
\text { medium-low } \\
\text { tech }
\end{array} & \begin{array}{c}
\text { medium- } \\
\text { high-tech }
\end{array}
\end{array} \text { high-tech }
$$

Enterprise received central government financial support for innovative $5.8 \%$

$$
9.5 \%
$$
activities in 1996

Company was involved with innovation related Government programmes since 1994

$\begin{array}{llll}12.0 \% & 15.3 \% & 21.5 \% & 28.6 \%\end{array}$


Table 15: Proportion of turnover from technological new, improved or unchanged products.

$\begin{array}{ccc}\text { technological } & \begin{array}{c}\text { improved } \\ \text { products }\end{array} & \begin{array}{c}\text { unchanged } \\ \text { products }\end{array}\end{array}$

low-tech

$4.7 \%$

$12.8 \%$

$82.5 \%$

medium-low-

tech

$6.1 \%$

$16.4 \%$

$77.4 \%$

medium-high-

tech

$9.3 \%$

$18.1 \%$

$72.7 \%$

high-tech

$13.7 \%$

$20.4 \%$

$65.2 \%$

Table 16: Percentage change in employment, turnover and exports. CIS 1994 - 1996.

emplyees turnover exports

$\begin{array}{lccc}\text { low-tech } & 13.3 \% & 25.5 \% & 86.2 \% \\ \begin{array}{l}\text { medium-low- } \\ \text { tech } \\ \text { medium-high- } \\ \text { tech }\end{array} & 13.0 \% & 29.7 \% & 93.1 \% \\ \text { high-tech } & 11.7 \% & 48.0 \% & 84.2 \% \\ & 16.1 \% & 35.8 \% & 138.4 \%\end{array}$




\section{Appendix I}

Table 3a: R\&D intensity, OECD - 10, 14, 1990, 1995.

\begin{tabular}{|c|c|c|c|c|c|}
\hline Industry & $\begin{array}{c}\text { ISIC } \\
\text { Rev. } 3 \\
\end{array}$ & $\begin{array}{c}1990 \\
\text { OECD - 10 } \\
\text { R\&D } \\
\text { as \% of } \\
\text { value added } \\
\end{array}$ & Rank & $\begin{array}{c}1995 \\
\text { OECD - } 14 \\
\text { R\&D } \\
\text { as \% of } \\
\text { value added }\end{array}$ & Rank \\
\hline \multicolumn{6}{|l|}{ High-tech } \\
\hline Aerospace & 353 & 36.25 & 1 & 39.40 & 1 \\
\hline Office, computing equip. & 30 & 30.49 & 2 & 25.30 & 2 \\
\hline Pharmaceuticals & 2423 & 21.57 & 3 & 22.40 & 3 \\
\hline Radio, TV, communication equip. & 32 & 18.65 & 4 & 17.20 & 5 \\
\hline \multicolumn{6}{|l|}{ Medium-high-tech } \\
\hline Scientific instruments & 33 & 11.19 & 6 & 19.50 & 4 \\
\hline Motor vehicels & 34 & 13.70 & 5 & 12.70 & 6 \\
\hline Electrical machinery & 31 & 7.63 & 9 & 8.90 & 7 \\
\hline Chemicals & $24 \mathrm{e} 2423$ & 8.96 & 7 & 7.70 & 8 \\
\hline Other transport & $35 \mathrm{e} 351+353$ & 3.97 & 11 & 7.00 & 9 \\
\hline Non-electrical machinery & 29 & 4.58 & 10 & 5.60 & 10 \\
\hline \multicolumn{6}{|l|}{ Medium-low-tech } \\
\hline Rubber, plastic & 25 & 3.02 & 12 & 2.80 & 12 \\
\hline Shipbuilding & 351 & 2.13 & 15 & 2.20 & 14 \\
\hline Basic metals* & 27 & 2.98 & 13 & 2.30 & 13 \\
\hline Non-metalic mineral prod. & 26 & 2.20 & 14 & 1.90 & 15 \\
\hline Fabricated metal prod. & 28 & 1.39 & 16 & 1.20 & 16 \\
\hline Petroleum refineries & 23 & 8.43 & 8 & 3.60 & 11 \\
\hline \multicolumn{6}{|l|}{ Low-tech } \\
\hline Wood, paper, publishing* & $20-22,36-37$ & 0.92 & 18 & 1.13 & 17 \\
\hline Textiles, apparel, leather & $17-19$ & 0.65 & 19 & 0.80 & 19 \\
\hline Food, beverages, tobacco & $15-16$ & 1.14 & 17 & 1.10 & 18 \\
\hline Total & & 9.47 & & 9.62 & \\
\hline
\end{tabular}

*unweighted average calculated. 
Table 3b: R\&D intensity, OECD - 14 and OECD - UK, 1995 and 1996.

\begin{tabular}{|c|c|c|c|c|c|}
\hline Industry & $\begin{array}{c}\text { ISIC } \\
\text { Rev. } 3 \\
\end{array}$ & $\begin{array}{c}1995 \\
\text { OECD - } 14 \\
\text { R\&D } \\
\text { as \% of } \\
\text { value added } \\
\end{array}$ & Rank & $\begin{array}{c}1996 \\
\text { OECD - UK } \\
\text { R\&D } \\
\text { as \% of } \\
\text { value added } \\
\end{array}$ & Rank \\
\hline \multicolumn{6}{|l|}{ High-tech } \\
\hline Aerospace & 353 & 39.40 & 1 & 25.32 & 2 \\
\hline Office, computing equip. & 30 & 25.30 & 2 & 4.77 & 10 \\
\hline Pharmaceuticals & 2423 & 22.40 & 3 & 43.58 & 1 \\
\hline Radio, TV, communication equip. & 32 & 17.20 & 5 & 12.56 & 4 \\
\hline \multicolumn{6}{|l|}{ Medium-high-tech } \\
\hline Scientific instruments & 33 & 19.50 & 4 & 7.04 & 7 \\
\hline Motor vehicels & 34 & 12.70 & 6 & 9.72 & 6 \\
\hline Electrical machinery & 31 & 8.90 & 7 & 9.80 & 5 \\
\hline Chemicals & $24 \mathrm{e} \times 2423$ & 7.70 & 8 & 5.46 & 9 \\
\hline Other transport & $35 \mathrm{ex} 351+353$ & 7.00 & 9 & 6.23 & 8 \\
\hline Non-electrical machinery & 29 & 5.60 & 10 & 4.59 & 11 \\
\hline \multicolumn{6}{|l|}{ Medium-low-tech } \\
\hline Rubber, plastic & 25 & 2.80 & 12 & 0.94 & 16 \\
\hline Shipbuilding & 351 & 2.20 & 14 & 1.77 & 12 \\
\hline Basic metals & 27 & 2.30 & 13 & 1.01 & 14 \\
\hline Non-metalic mineral prod. & 26 & 1.90 & 15 & 1.16 & 13 \\
\hline Fabricated metal prod. & 28 & 1.20 & 16 & 0.86 & 17 \\
\hline Petroleum refineries & 23 & 3.60 & 11 & 13.74 & 3 \\
\hline \multicolumn{6}{|l|}{ Low-tech } \\
\hline Wood, paper, printing, publishing* & $20-22,36-37$ & 1.13 & 17 & 0.30 & 19 \\
\hline Textiles, apparel, leather & $17-19$ & 0.80 & 19 & 0.35 & 18 \\
\hline Food, beverages, tobacco & $15-16$ & 1.10 & 18 & 1.01 & 14 \\
\hline Total & & 9.62 & & 5.16 & \\
\hline
\end{tabular}

*unweighted average 
Table 3c: R\&D intensity, CIS and OECD, 1996 and 1990.

( $N=47,841$, weight2 applied, turnover averages 1994 and 1996)

\begin{tabular}{|c|c|c|c|c|c|c|c|}
\hline Industry Classification & $\begin{array}{c}\text { UK SIC } \\
1992\end{array}$ & $\begin{array}{c}1996 \\
\text { CIS } \\
\text { R\&D } \\
\text { as \% of } \\
\text { turnover }\end{array}$ & Rank & $\begin{array}{c}1996 \\
\text { OECD - UK } \\
\text { R\&D } \\
\text { as \% of } \\
\text { production }\end{array}$ & Rank & $\begin{array}{c}1990 \\
\text { OECD - 10 } \\
\text { R\&D } \\
\text { as \% of } \\
\text { production }\end{array}$ & Rank \\
\hline \multicolumn{8}{|l|}{ High-tech } \\
\hline Aircraft & 353 & 0.56 & 10 & 8.04 & 2 & 14.98 & 1 \\
\hline Office \& computing equip. & 30 & 3.20 & 2 & 1.28 & 11 & 11.46 & 2 \\
\hline Pharmaceutical & 244 & 3.14 & 3 & 17.67 & 1 & 10.47 & 3 \\
\hline Radio, TV, communication & 32 & 2.19 & 4 & 4.66 & 3 & 8.03 & 4 \\
\hline \multicolumn{8}{|l|}{ Medium-high-tech } \\
\hline Scientific instruments & 33 & 4.17 & 1 & 3.11 & 5 & 5.10 & 5 \\
\hline Motor vehicles & 34 & 0.46 & 13 & 2.90 & 6 & 3.41 & 6 \\
\hline Electr. machines & 31 & 0.96 & 9 & 4.03 & 4 & 2.81 & 8 \\
\hline Chemicals & $24 \mathrm{e} \times 244$ & 1.24 & 7 & 1.98 & 9 & 3.20 & 7 \\
\hline Other transports & $35 \mathrm{e} 351+353$ & 2.04 & 5 & 2.03 & 8 & 1.58 & 10 \\
\hline Non-electr. machinery & 29 & 1.82 & 6 & 1.84 & 10 & 1.74 & 9 \\
\hline \multicolumn{8}{|l|}{ Medium-low-tech } \\
\hline Rubber \& plastic prod. & 25 & 0.37 & 16 & 0.38 & 15 & 1.07 & 11 \\
\hline Shipbuilding & 351 & 0.54 & 11 & 0.77 & 12 & 0.74 & 15 \\
\hline Basic metals & 27 & 0.16 & 19 & 0.30 & 17 & 0.79 & 14 \\
\hline Non-metallic mineral prod. & 26 & 0.99 & 8 & 0.55 & 13 & 0.93 & 13 \\
\hline Metal prod.l & 28 & 0.52 & 12 & 0.39 & 14 & 0.63 & 16 \\
\hline Petroleum refineries & 23 & 0.41 & 14 & 2.63 & 7 & 0.96 & 12 \\
\hline \multicolumn{8}{|l|}{ Low-tech } \\
\hline Wood, paper, printing, publishing* & $20-22,36-37$ & 0.34 & 17 & 0.13 & 19 & 0.37 & 17 \\
\hline Textiles, apparel \& leather & $17-19$ & 0.39 & 15 & 0.15 & 18 & 0.23 & 19 \\
\hline Food, beverages \& tobacco & $15-16$ & 0.19 & 18 & 0.32 & 16 & 0.34 & 18 \\
\hline Total & & 0.93 & & 1.89 & & 3.62 & \\
\hline
\end{tabular}

*CIS values: weighted average

OECD values: unweighted avereage 
Table 5a: R\&D intensity, CIS, 1996, SIC 341 single responses.

$\begin{array}{cc}\text { Enterprise } & \begin{array}{c}\mathbf{1 9 9 6} \\ \text { CIS } \\ \text { R\&D intensity } \\ \text { as \% of } \\ \text { turnover }\end{array} \\ 1 & 0.00 \\ 2 & 0.00 \\ 3 & 0.05 \\ 4 & 0.45 \\ 5 & 0.51 \\ 6 & 0.96 \\ 7 & 2.98 \\ \text { Average } & 0.71\end{array}$


Sources within the enterprise have provided technological knowledge for innovation

Other enterprises within the enterprise group have provided technological knowledge for innovation

Competitors have provided technological knowledge for innovation

Clients or customers have provided technological knowledge for innovation

Consultancy enterprises have provided technological knowledge for innovation

Suppliers of equipment, materials, components or software have provided technological knowledge for innovation

Internal, supply chain and competitors. average

Universities or HEIs have provided technological knowledge for innovation

Government institutes have provided technological knowledge for innovation

Private non-profit research institutes have provided

technological knowledge for innovation

Patenet disclosures have provided technological knowledge for innovation

Public sector and non-profit orgs. average

Professional conferences, meetings, journals have provided technological knowledge for innovation

Computer based information networks have provided

technological knowledge for innovation

Fairs, exhibitions have provided technological knowledge for innovation

Networking institutions. average

Enviromental regulations have provided technological knowledge for innovation

Health and Safety regulations have provided technological

knowledge for innovation

Product Standards have provided technological knowledge for innovation

Regulations and standards. average

Research Associations or other independent Research and Technology Organisations have provided knowledge

Training and Enterprise Councils have provided technological knowledge for innovation

Business Links have provided technological knowledge for innovation

Trade associations have provided technological knowledge for innovation

Business links. average

\begin{tabular}{|c|c|c|c|}
\hline low-tech & $\begin{array}{l}\text { medium-low- } \\
\text { tech }\end{array}$ & $\begin{array}{l}\text { medium- } \\
\text { high-tech }\end{array}$ & high-tech \\
\hline $44.2 \%$ & $47.9 \%$ & $62.2 \%$ & $66.9 \%$ \\
\hline $22.5 \%$ & $24.8 \%$ & $35.7 \%$ & $41.0 \%$ \\
\hline $27.6 \%$ & $24.3 \%$ & $37.8 \%$ & $38.8 \%$ \\
\hline $40.8 \%$ & $42.9 \%$ & $62.4 \%$ & $65.2 \%$ \\
\hline $17.6 \%$ & $15.1 \%$ & $19.2 \%$ & $19.7 \%$ \\
\hline $46.2 \%$ & $43.7 \%$ & $51.4 \%$ & $50.6 \%$ \\
\hline $33.1 \%$ & $33.1 \%$ & $44.8 \%$ & $47.0 \%$ \\
\hline $12.4 \%$ & $17.6 \%$ & $25.8 \%$ & $26.4 \%$ \\
\hline $4.3 \%$ & $6.7 \%$ & $9.4 \%$ & $12.4 \%$ \\
\hline $5.1 \%$ & $4.2 \%$ & $5.4 \%$ & $5.6 \%$ \\
\hline $4.9 \%$ & $8.4 \%$ & $12.9 \%$ & $11.2 \%$ \\
\hline $6.7 \%$ & $9.2 \%$ & $13.4 \%$ & $13.9 \%$ \\
\hline $25.8 \%$ & $19.9 \%$ & $33.6 \%$ & $41.0 \%$ \\
\hline $9.1 \%$ & $6.7 \%$ & $15.3 \%$ & $25.8 \%$ \\
\hline $40.2 \%$ & $31.3 \%$ & $44.6 \%$ & $52.8 \%$ \\
\hline $25.0 \%$ & $19.3 \%$ & $31.1 \%$ & $39.9 \%$ \\
\hline $20.5 \%$ & $24.6 \%$ & $28.4 \%$ & $19.7 \%$ \\
\hline $24.9 \%$ & $32.0 \%$ & $33.6 \%$ & $28.1 \%$ \\
\hline $19.9 \%$ & $25.6 \%$ & $38.0 \%$ & $33.7 \%$ \\
\hline $21.8 \%$ & $27.4 \%$ & $33.3 \%$ & $27.2 \%$ \\
\hline $13.0 \%$ & $11.4 \%$ & $16.7 \%$ & $15.2 \%$ \\
\hline $6.5 \%$ & $7.2 \%$ & $6.6 \%$ & $7.3 \%$ \\
\hline $9.5 \%$ & $8.4 \%$ & $11.5 \%$ & $13.5 \%$ \\
\hline $16.6 \%$ & $14.6 \%$ & $18.5 \%$ & $23.0 \%$ \\
\hline $11.4 \%$ & $10.4 \%$ & $13.3 \%$ & $14.7 \%$ \\
\hline
\end{tabular}




\section{Appendix II: Explanatory notes SIC 34, the manufacture of motor vehicles.}

\section{1}

this class includes manufacture of:

- motor cars and other motor vehicles principally designed for the transport of persons: personal passenger motor cars, passenger motor vehicles designed to negotiate unusual terrain (snow mobiles, golf carts, cross-country cars, amphibian motor vehicles) and public-transport type passenger motor vehicles, i.e. busses-motor vehicles for the transport of goods: ordinary lorries and vans (flat, tarpaulin covered, closed, etc.); lorries with automatic discharging devices, tankers, drop frame lorries, refuse collectors, etc.; special purpose motor lorries and trucks (motor breakdown lorries, armoured cars, fire-engines, street sweepers, mobile medical and dental clinics, travelling libraries, etc.).

- over-the-road tractors for semi-trailers.

- chassis fitted with engines for the motor vehicles described above.

- compression-ignition or spark-ignition reciprocating or rotary internal combustion piston engines of types chiefly used to power motor vehicles.

- Exclusion: Manufacture of electrical equipment for motor vehicles is classified in class 3190 (Manufacture of other electrical equipment n.e.c.).

\section{2}

This class includes manufacture of:

- bodies (including cabs) designed to be mounted on motor vehicle chassis, bodies for vehicles without chassis and unit construction bodies; bodies for passenger vehicles, lorries and special purpose vehicles; bodies of metal, wood, plastics or combinations of these or other materials.

- trailers and semi-trailers designed to be drawn by motor vehicles; trailers and semi-trailers of the caravan type used for housing or camping, for transport of goods (e.g. tankers, removal trailers, motor car carriers, ammunition limbers, etc.), for transport of passengers and for other purposes including "road-rail" trailers.

- parts of trailers and semi-trailers.

- containers (including containers for the transport of fluids) specially designed and equipped for carriage by one or more modes of transport.

- Exclusions: Manufacture of trailers and semi-trailers specially designed for use in agriculture is classified in class 2921 (Manufacture of agricultural and forestry machinery). Trailers of that type are frequently provided with couplings permitting attachment of choppers, spreaders, or other devices or are fitted with attachments. Manufacture of trailer mounted agricultural machinery is also classified in class 2921. Manufacture of parts and accessories of bodies for motor vehicles is classified in class 3430 .

\section{3}

This class includes manufacture of parts and accessories for motor vehicles including their bodies and engines: brakes, gear boxes, axles, road wheels, suspension shock absorbers, radiators, silencers, exhaust pipes, clutches, steering wheels, steering columns and steering boxes and other parts and accessories not elsewhere classified.

Exclusions: Manufacture of motor vehicle engines is classified in class 3410 (Manufacture of motor vehicles). Manufacture of chassis fitted with engines is also classified in class 3410Manufacture of bodies for motor vehicles is classified in class 3420 . 


\section{Reference}

Audretsch, D. (1995), 'Innovation, growth and survival' International Journal of Industrial Organisation, 13: 441-57.

Brynjolfsson, E. and Hitt, L. M. (2000), 'Beyond Computation: Information Technology, Organizational Transformation and Business Transformation and Business Performance' Journal of Economic Perspectives, 14, 4: 23-48.

Cohen, W. and Levinthal, D. (1990), 'Absorptive Capacity: A New Perspective on Learning and Innovation' Administrative Science Quarterly 35, 1: 128-52.

Cohen, W. and Levinthal, D. (1989), 'Innovation and Learning: The two Faces of R\&D’ Economic Journal, 99: 569-96.

Cox, H., Mowatt, S. and Prevezer, M (forthcoming), 'The Firm in the Information Age: Organizational Responses to Technological Change in the Processed Foods Sector', Industrial and Corporate Change.

Department of Trade and Industry (1996), Community Innovation Survey, Manufacturing Sector, London.

Department of Trade and Industry (1998), 'UK results from the Community Innovation Survey', Economic Trends, No. 539, London.

Edquist, C. Hommen, L. and Sellenthin, M. (forthcoming), Innovation in Swedish Manufacturing: An Overview and Descriptive Analysis of Data from CIS II, Linköping University: Department of Technology and Social Change.

Feldman, M. (1994), The Geography of Innovation, Dordrecht:Kluwer Academic Publishers.

Geroski, P, Machin, S. and van Reenen. J. (1993), 'The profitability of innovating 
firms' Rand Journal of Economics, 24: 198-211.

Jaffe, A (1986), 'Technological opportunity and spillovers from R\&D: evidence from firms' patents, profits and market value' American Economic Review, 76: 984-1001.

Levin, R., Klevorick, A., Nelson, R. and Winter, S. (1987), 'Appropriating the Returns from Industrial Research and Development', Brookings Papers on Economic Activity, 3, 783-820.

Mansfield, E. (1986), 'Patents and Innovation: An Empirical Study' Management Science, 32: 173-181.

Nelson, R. and Winter, S. (1982), An Evolutionary Theory of Economic Change, Cambridge MA: Harvard University Press.

Nelson, R. (1993), National Systems of Innovation, Oxford: Oxford University Press.

Nelson, R. and Rosenberg, N (2000) 'Science, Technological Advance and Economic Growth' in: The Dynamic Firm (eds) Chandler, A. D., Hagstrom, P. and Solvell, O., Oxford: Oxford University Press.

Organisation for Economic Co-operation and Development (1994), Main Definitions and Conventions for the Measurement of Research and Experimental Development (R\&D). A Summary of the Frascati Manual 1993, Paris: OECD/GD(94)84.

Organisation for Economic Co-operation and Development (1999), Main Industrial Indicators 1980 - 1997, Paris: OECD Statistics.

Organisation for Economic Co-operation and Development (2000a), Research and Development Expenditure in Industry 1977 - 1998, Paris: OECD Statistics.

Organisation for Economic Co-operation and Development (2000b), Structural analysis 2000, Paris:OECD Statistics. 
Pavitt, K. (1987), On the nature of technology, Mimeo: University of Sussex, Science Policy Research Unit.

Pavitt, K., Robson, M. and Townsend, J. (1987), 'The size distribution of innovating firms in the UK 1945-1983', Journal of Industrial Economics, 35: 297-316.

Porter, M. E. (1990), The Competitive Advantage of Nations, London: Macmillan.

Stoneman, P. (1980), 'The rate of imitation, learning and profitability', Economics Letters, 6: 1179-83.

Stoneman, P. (1990), 'Technological diffusion, horizontal product differentiation and adaptation costs' Economica, 57: 49-62.

Stoneman, P. (ed) (1994), Handbook of the Economics of Innovation and Technical Change, Oxford: Basil Blackwell.

Swann, P. M., Prevezer, M. and Stout, D. (1998), The Dynamics of Industrial Clustering: International Comparisons in Computing and Biotechnology, Oxford: Oxford University Press.

United Nations Statistics Division (2001), Online Classifications Registry, http://esa.un.org/unsd/cr/registry/regcst.asp?Cl=2\&Lg=1. 